\author{
KATARZYNA TOMASZEWSKA \\ ORCID: 0000-0003-4024-0036 \\ Uniwersytet Wrocławski
}

\title{
ADMINISTRACYJNOPRAWNE, CYWILNOPRAWNE ORAZ INNE FORMY DZIAŁANIA W OBREBBIE POSTĘPOWAŃ O UDOSTĘPNIENIE INFORMACJI W CELU PONOWNEGO JEJ WYKORZYSTYWANIA
}

\begin{abstract}
Abstrakt: Udostępnienie informacji, odmowa udostępnienia, ustalenie warunków jako zachowania występujące w obrębie postępowań regulowanych ustawą z dnia 25 lutego 2016 roku o ponownym wykorzystywaniu informacji sektora publicznego przybierają formy, które są powszechnie wykorzystywane w ramach działalności administracji publicznej. Chodzi w tym wypadku o działania faktyczne, kontrakty oraz decyzje administracyjnie doktrynalnie określane jako prawne formy działania, a wykorzystywane przez podmioty zobowiązane informacyjnie wówczas, gdy podmiot realizuje swoje zainteresowanie informacyjnie w trybie wnioskowym, jak również niezależnie od zachowania strony uprawnionej z urzędu (bezwnioskowo). Omówieniu niniejszych kategorii działania, przywołaniu ich właściwości oraz znaczenia w procesie udostępniania informacji w celu ponownego wykorzystywania poświęcone jest niniejsze opracowanie.
\end{abstract}

Słowa kluczowe: ponowne wykorzystywanie, forma działania, informacja sektora publicznego, decyzja, akt

\section{WPROWADZENIE}

Związek prawa dostępu do informacji publicznej a prawa do informacji w celu ponownego wykorzystywania jest niezaprzeczalny. W wielu aspektach bowiem uwidaczniają się podobieństwa obu praw. G. Sibiga podkreśla, że „dostęp do informacji oraz ponowne jej wykorzystywanie pozostają względem siebie w określonej relacji" . Nieprzypadkowo w przeszłości realizacja obu uprawnień uregulowana została jednym aktem prawnym. Niemniej jednak potrzeba uczynie-

${ }^{1}$ G. Sibiga, Ponowne wykorzystywanie informacji sektora publicznego 2017. Akty prawne i ich omówienie, Wrocław 2017, s. 27; zob. też P. Szustakiewicz, Wzajemny stosunek do dwóch ustaw tworzacych polski system dostępu do informacji publicznej, „Informacja w administracji publicznej” 2017, nr 3, Legalis (dostęp: 8.03.2021). 
nia rozwiązań dotyczących ponownego wykorzystywania bardziej przejrzystymi i łatwiejszymi w stosowaniu, przesądziła o przyjęciu odmiennego sposobu uregulowania ${ }^{2}$. Uprzednie skumulowanie i ,wepchnięcie" materii dotyczącej ponownego wykorzystywania informacji do zawartości ustawy z dnia 6 września 2001 roku o dostępie do informacji publicznej ${ }^{3}$ (dalej: u.d.i.p.) zostało zastąpione przyjęciem odrębnego, ale i przy tym równorzędnego do u.d.i.p. aktu prawnego - ustawy z dnia 25 lutego 2016 roku o ponownym wykorzystywaniu informacji sektora publicznego 4 (dalej: u.p.w.i.s.p.). Dało to tym samym wyraz ukształtowania instytucji w pewnym sensie niezależnej i różnej, ale i równie istotnej, co dostęp do informacji, zasługującej na swoje własne, odrębne uregulowania.

Częściowego podobieństwa, ale i częściowej odmienności obu uprawnień, można doszukiwać się po stronie prawnych form działania wykorzystywanych przez podmioty zobowiązane informacyjnie $\mathrm{w}$ obrębie postępowań. W ramach procedury związanej z udostępnianiem informacji publicznej (wedle uregulowań u.d.i.p.), ogół działań i czynności podmiotów, na których spoczywa zobowiązanie w przedmiocie udostępnienia informacji publicznej, można podzielić na działania faktyczne (ściślej określając czynności materialnotechniczne) oraz akty administracyjne. Z kolei w obrębie postępowań o udostępnienie informacji w celu ponownego wykorzystywania informacji sektora publicznego (dalej: ISP), uwidacznia się występowanie zarówno form typowych dla tego rodzaju postępowań — administracyjnoprawnych, oraz mniej typowych — cywilnoprawnych, które pozostają $\mathrm{w}$ nierozerwalnym związku $\mathrm{z}$ działaniami faktycznymi podmiotów zobowiązanych informacyjnie.

Zważywszy na celowość istnienia kategorii prawnej formy działania oraz definiowanie sprowadzające się do określenia jej jako typu konkretnej czynności bądź też jako rodzaju podejmowanego działania ${ }^{5}$, doniosłość jej występowania w obrębie rozmaitych procedur administracyjnych, w tym i quasi-administracyjnych, jest niepodważalna. Słusznie zauważa A. Wiktorowska, że ich istotą jest służba na rzecz bezpieczeństwa i pewności prawa, albowiem ich prawne sklasyfikowanie i opisanie ma gwarantować zorganizowane, racjonalne i efektywne działanie, przez nieustanne korzystanie i powielanie przez ich adresatów pewnych standardów oraz wzorców postępowania w konkretnej działalności 6 . Przytoczone twierdzenia odwołują się w sposób bezpośredni do występujących w obrębie

${ }^{2}$ K. Chałubińska-Jentkiewicz, Ponowne wykorzystanie informacji sektora publicznego (reuse). Komentarz do ustawy, Warszawa 2018, s. 96.

3 Dz.U. z 2020 r. poz. 2176.

${ }^{4}$ Dz.U. z 2019 r. poz. 1446; zob. też ustawę z dnia 11 sierpnia 2021 r. o otwartych danych i ponownym wykorzystywaniu informacji sektora publicznego (Dz.U. z 2021 r. poz. 1641). Data wejścia w życie niniejszego aktu została ustalona na 8 grudnia $2021 \mathrm{r}$.

5 J. Zimmermann, Prawo administracyjne, Warszawa 2008, s. 276; zob. też K.M. Ziemski, Indywidualny akt administracyjny jako forma prawna działania administracji, Poznań 2005, s. 138.

6 A. Wiktorowska, Kierunki zmian w teorii prawnych form działania administracji, [w:] Koncepcja systemu prawa administracyjnego, red. J. Zimmermann, Warszawa 2007, s. 359 n. 
działania administracji sposobów działania jej podmiotów, czyli organów administracji publicznej oraz innych podmiotów administrujących. Ze względu na zawartość art. 4 u.d.i.p. oraz art. 3 u.p.w.i.s.p. zasadnym wydaje się rozciągnięcie ich „zasięgu” na działalność podmiotów określanych mianem zobowiązanych informacyjnie, które uruchamiając procedurę dostępową, posługują się prawnie ugruntowanymi i teoretycznie opisanymi standardami postępowania. Pozostaje to w ścisłym związku z twierdzeniem, w świetle którego administracja podejmuje się działania $\mathrm{w}$ formach przewidzianych przez prawo. Bez wątpienia do takich też sposobów działania należy odwołać się na gruncie uregulowań u.p.w.i.s.p. Scharakteryzowaniu niniejszych, przy jednoczesnym uwypukleniu ich szczególnych cech jako działań występujących w quasi-postępowaniu administracyjnym, poświęcone jest przedmiotowe opracowanie.

\section{INNE DZIAŁANIA W OBRĘBIE POSTĘPOWANIA O UDOSTĘPNIENIE ISP}

Odwołując się do doktrynalnych kwalifikacji determinujących rodzaj, istotę, a w szczególności ważność poszczególnych kategorii działania podmiotów administracji publicznej, trzeba wskazać, że przyjęta na gruncie niniejszego opracowania kolejność ich omówienia jest nietypowa, bo traktująca formę decyzji jako „coś”, co nie ma podstawowego znaczenia, bo co do zasady nie prowadzi do osiągnięcia celu zgodnego z intencją podmiotu zainteresowanego, czyli uzyskania, a następnie korzystania z ISP bezwarunkowo ${ }^{7}$. Teoretyczne rozważania z zakresu prawa administracyjnego, odnoszące się do kategorii działań administracji publicznej wskazują, że tego rodzaju określenia - o fakultatywnym znaczeniu są raczej zarezerwowane dla działań faktycznych, a nie aktów administracyjnych. „Koncepcja działań faktycznych obowiązująca w nauce prawa administracyjnego zakłada, że działania faktyczne są kategorią działań uzupełniającą działania prawne tej administracji"8. W obliczu uregulowań u.p.w.i.s.p. sytuacja wygląda odmiennie i jest jak najbardziej prawidłowa z punktu widzenia problematyki ponownego wykorzystywania ISP. Traktowane w ujęciu ogólnym niejako dodatkowo, tak zwane inne działania administracji publicznej, pośród wszystkich dopuszczalnych form działania w procedurze związanej z udostępnianiem ISP, zajmują naczelne miejsce i posiadają podstawowe znaczenie. Jednostki oczekujące określonej informacji lub też sięgające samodzielnie po informację są zainteresowane aktywnym działaniem podmiotu zobowiązanego - działaniem podejmowanym bezwarunkowo i bezpłatnie oraz przynoszącym korzyść informacyjną najszybciej,

7 Tego rodzaju twierdzenie nie może i nie ma pełnego zastosowania w zakresie decyzji wskazujących na warunki, które mają towarzyszyć korzystaniu z ISP.

${ }^{8}$ Prawo administracyjne, red. J. Boć, Wrocław 2010, s. 340. 
jak tylko to jest możliwe. To one bowiem są związane z pozytywnym załatwieniem wniosku zainteresowanego informacyjnie lub też z działaniem podejmowanym przez zobowiązanego niejako $\mathrm{z}$ urzędu, a prowadzącym do powszechnego udostępnienia ISP. Uwzględniając zawartość art. 23 u.p.w.i.s.p., należy zauważyć, że pkt 1 wskazanej regulacji odwołuje się do pozytywnego załatwienia sprawy przez czynność materialnotechniczną. Podmiot zobowiązany, po rozpatrzeniu wniosku zainteresowanego, przekazuje ISP w celu ponownego jej wykorzystywania (w sposób wyznaczony przez wnioskodawcę i przy użyciu formy przez niego określonej). Podobnym stanowiskiem (mimo braku wyraźnego określenia przez ustawodawcę) można by się posłużyć w kontekście bezwnioskowego udostępnienia ISP za pomocą BIP, CR lub w inny sposób, o którym mowa między innymi $\mathrm{w}$ art. 11 ust. 2 u.p.w.i.s.p. Adekwatnego do oczekiwań zainteresowanego finału postępowania (choć niezwiązanego z przekazywaniem ISP) można upatrywać również w pkt 2 art. 23 u.p.w.i.s.p. Odnosi się on bowiem do informowania wnioskodawcy o braku warunków ponownego wykorzystywania ISP wówczas, gdy zainteresowany znajduje się już w jej posiadaniu. Tego rodzaju powiadomienie wyczerpuje znamiona czynności materialnotechnicznej. Co więcej, zgodnej $\mathrm{z}$ aspiracjami podmiotu zainteresowanego $i$ jedynej posiadającej tego rodzaju charakter pośród szeregu komunikatów pochodzących od zobowiązanego, możliwych do wystąpienia w omawianej procedurze. Chodzi w tym wypadku o informowanie zainteresowanego o okolicznościach, które uniemożliwiają dokonanie merytorycznego rozstrzygnięcia wobec jego zainteresowania informacyjnego. Dzieje się tak w następujących przypadkach: wniosek nie jest wnioskiem o ponowne wykorzystywanie ISP; informacja objęta wnioskowaniem nie znajduje się w posiadaniu zobowiązanego informacyjnie; informacja objęta oczekiwaniem informacyjnym nie stanowi ISP wedle uregulowań u.p.w.i.s.p.; ISP, której oczekuje zainteresowany, została już udostępniona w trybie bezwnioskowym wraz z określeniem warunków i ustaleniem opłat z tym związanych; udostępnienie informacji oczekiwanej podlega odrębnym uregulowaniom, w tym również $\mathrm{w}$ związku $\mathrm{z}$ wymaganiem wykazania interesu prawnego lub faktycznego na podstawie przepisów szczególnych ${ }^{9}$.

Zawartość uregulowań u.p.w.i.s.p. przesądza o przyznaniu szczególnego znaczenia działaniom faktycznym, ale nie wpływa na charakterystykę samego udostępnienia jako czynności materialnotechnicznej. W ujęciu ogólnym prezentowanym przez doktrynę prawa administracyjnego działania faktyczne nie tworzą kategorii przeciwnej do działań prawnych, same zresztą, mimo swojego nazewnictwa, są działaniami podejmowanymi i realizowanymi na podstawie prawa i w granicach obowiązujących przepisów, są kategorią prawnie dopuszczalną i niewadliwą, tworzącą narzędzie stosowania prawa, pozostającą w ścisłym związ-

9 Zob. B. Fisher et al., Ustawa o ponownym wykorzystywaniu informacji sektora publicznego. Komentarz, LEX (dostęp: 3.03.2021). 
$\mathrm{ku} \mathrm{z}$ techniką administrowania oraz oddziaływania administracji na stosunki prawa materialnego ${ }^{10}$. Wbrew teoriom czynności materialnotechniczne uregulowane treścią u.p.w.i.s.p. nie są wyłącznie instrumentami mającymi na celu przygotowanie podłoża działań prawnych, nie wywołując przy tym żadnych bezpośrednich skutków prawnych ${ }^{11}$. Wręcz przeciwnie, są czynnościami warunkującymi proces ponownego wykorzystywania ISP (jego wystąpienie lub brak). Uregulowania u.p.w.i.s.p., nosząc znamiona norm ustrojowych (podobnie jak u.d.i.p.), regulują charakter, treść, formę oraz przebieg czynności materialnotechnicznych. Samo zaś przekazanie i udostępnienie ISP jest zabiegiem przeprowadzanym:

1. dwojako: pierwotnie (z urzędu i bezwnioskowo, za pomocą posiadanych systemów teleinformatycznych), w tym przy wykorzystaniu powszechnie dostępnych i nierzadko elektronicznych (teleinformatycznych) publikatorów (BIP, CR) oraz następczo (tradycyjnie, w oparciu o uprzednio przedłożony wniosek);

2. bezpłatnie, chyba że konieczność przygotowania ISP lub też jej przekazania wedle oczekiwania zainteresowanego pociąga za sobą określone koszty;

3. bezwarunkowo, chyba że zachodzi konieczność odstępstwa od zasady swobodnego udostępnienia informacji w celu ponownego wykorzystania ze względu na jej charakter lub też z innych powodów (art. 13 ust. 2 i 3 u.p.w.i.s.p.) ${ }^{12}$;

4. niezwłocznie (tak szybko, jak tylko istnieje taka możliwość), jeśli chodzi o realizację procedury w trybie wnioskowym, nie później jednak niż w ciągu 14 dni, chyba że zaistnieją okoliczności powodujące konieczność opóźnienia procedury, nie dłużej jednak niż o dwa miesiące od momentu ubiegania się o informację;

5. powszechnie i, co ważne, niezależnie od przyjętego sposobu udostępnienia. $\mathrm{Z}$ racji działania samoistnego (podejmowanego z urzędu) powszechność w obrębie tak zwanego trybu bezwnioskowego nie budzi zaskoczenia. Informacja upubliczniona, między innymi za pomocą BIP, ma możność dotarcia do każdego zainteresowanego, bez wyjątku. Ustawodawca treścią art. 5 u.p.w.i.s.p. potwierdza dużą skalę realizacji procesu udostępnienia, również w zakresie trybu wnioskowego, albowiem każdemu przysługuje prawo do ponownego wykorzystywania ISP;

6. przy uwzględnieniu prawnie regulowanych ograniczeń w postaci konieczności zachowania ochrony informacji niejawnych, innych tajemnic ustawowo chronionych, ochrony prywatności osoby fizycznej, tajemnicy przedsiębiorcy, w związku z zawartością przepisów szczególnych i koniecznością respektowania sytuacji limitujących dostępność do informacji, o których mowa w art. 6 ust. 4 u.p.w.i.s.p. Powszechność udostępnienia (zarówno podmiotowa, jak i przedmiotowa), związana z szerokim zakresem procesu przekazywania i upubliczniania danych, nie jest jednoznaczna $\mathrm{z}$ całkowitym brakiem przeszkód prawnych w procesie jego realizacji. Mogą i są one określone treścią u.p.w.i.s.p., jak też przepisa-

10 Prawo administracyjne..., s. 340; J. Zimmermann, op. cit., s. 350.

11 J. Zimmermann, op. cit., s. 350.

12 Podmioty określone w art. 14 ust. 2 u.p.w.i.s.p. mogą określić również inne warunki ograniczające wykorzystywanie ISP. 
mi szczególnymi. Podobnie jeśli chodzi o przesłanki egzoneracyjne, przewidujące odstępstwa od zasady dopuszczalności limitowania procedury udostępnienia ISP (art. 6 ust. 2 zd. 2 u.p.w.i.s.p.).

\section{UMOWA JAKO FORMA DZIAŁANIA PODMIOTU ZOBOWIĄZANEGO INFORMACYJNIE}

Umowa jako jedno z działań administracji zajmuje to samo miejsce — obok aktu administracyjnego. W kreowanej przez doktrynę hierarchii wszystkich rodzajów (kategorii) działań nie jest stawiana ani wyżej, ani niżej, ale na tym samym poziomie jako forma równorzędna władczym sposobom działania. Inny jest jednak jej charakter. Istota umowy co do zasady przekreśla możliwość dysponowania właściwym w działalności podmiotów publicznych atrybutem władztwa administracyjnego. Współcześnie rola umów jako form działania w państwie prawnym nabiera coraz większego znaczenia. „Fakt wprowadzania do polskiego systemu prawnego niewładczych form działania administracji publicznej opartych na zasadach kooperacji, dyspozytywności i kontradyktoryjności należy ocenić pozytywnie, ale proces ten nie jest skoordynowany i nie następuje ewolucyjne"13. Jak zakładają teoretycy prawa administracyjnego: ,we współczesnym państwie prawnym jednostronność jest i powinna być łagodzona różnymi sposobami, a celowi temu służą takie zasady podstawowe jak subsydiarność i zasada decentralizacji”, dlatego też formy dwustronne (umowy) odgrywają coraz większą rolę, ale i tak są pozostawione $\mathrm{z}$ tyłu, $\mathrm{z}$ racji odbiegania od istoty gałęzi prawa administracyjnego opierającej się na władczości ${ }^{14}$.

Problematyka związana z ustawowo przewidzianą dopuszczalnością łamania reguły bezwarunkowości uwidacznia występowanie jednego ze sposobów dochodzenia przez strony do stanu zgodności (do stanu zawarcia umowy). W myśl art. 12 ust. 1 i 2 u.p.w.i.s.p. warunki ponownego wykorzystywania określone przez podmiot zobowiązany w odniesieniu do ISP udostępnionych na stronie podmiotowej BIP w CR oraz w inny sposób, jak również wysokość opłaty z tym związanej, tworzą ofertę zawierającą te warunki lub informacje o należnościach. Podmiot zobowiązany po rozpatrzeniu wniosku zainteresowanego między innymi składa ofertę zawierającą warunki ponownego wykorzystywania lub określa opłatę za ponowne wykorzystywanie, gdy jest ono związane z określeniem warunków albo $\mathrm{z}$ ustaleniem opłat (art. 23 ust. 1 pkt 3 u.p.w.i.s.p.). Wedle art. 66 § 1 ustawy z dnia 23 kwietnia 1964 roku - Kodeks cywilny (dalej: k.c.) $)^{15}$ oferta jest stanowczą

${ }^{13}$ Zob. A. Ostrowska, Koncepcja umowy administracyjnej na przyktadzie umowy o dotacje w świetle polskich i zagranicznych regulacji, „Prawo Budżetowe Państwa i Samorządu” 2018, nr 3, s. 11.

14 J. Zimmermann, op. cit., s. 331.

15 Dz.U. z 2020 r. poz. 1740. 
propozycją zawarcia umowy, określającą co najmniej konieczne postanowienia tej umowy ${ }^{16}$. To implikuje możliwość zawarcia kontraktu na skutek prostego przyjęcia oferty (także milcząco oraz konkludentnie). A zatem umowa zostaje zawarta, jeżeli adresat oferty przyjmie ją w czasie związania ofertą ${ }^{17}$. Przyjęcie jest też oświadczeniem woli (oblata), wyrażającym stanowczą i pozytywną odpowiedź na zawarcie umowy o treści określonej w ofercie ${ }^{18}$.

Zawartość uregulowań u.p.w.i.s.p. uwidacznia, że oferta, do której mają zastosowanie przepisy k.c., cechuje się brakiem dowolności. Twierdzenie to należy oprzeć na niemożności swobodnego kształtowania propozycji postanowień przyszłego kontraktu. Treść oferty musi mieścić się $\mathrm{w}$ granicach wyznaczonych przepisami u.p.w.i.s.p., które determinują kwestię warunków oraz opłat koniecznych do poniesienia $\mathrm{w}$ związku z ponownym wykorzystywaniem ISP ${ }^{19}$. Podstawowe znaczenie w tym przypadku ma zawartość art. 14 ust. 1 u.p.w.i.s.p., albowiem wyznacza katalog warunków będących elementem treściowym oferty, jak również ust. 2 wskazanej regulacji, dopuszczający możliwość rozszerzenia ich zakresu (wówczas gdy zobowiązanymi są muzea państwowe, muzea samorządowe, biblioteki publiczne, biblioteki naukowe i archiwa), a ograniczenia tym podyktowane (wyznaczeniem warunków) odnoszą się do określonego rodzaju działalności (komercyjnej lub też niekomercyjnej). Nie można też zapominać o obligatoryjności kształtowania warunków ponownego wykorzystywania ISP mających cechy utworu lub przedmiotu praw autorskich lub przedmiotu praw pokrewnych (art. 13 ust. 2 u.p.w.i.s.p.). W tym uwidacznia się szczególny charakter oferty, w żadnym jednak razie nieprowadzący do uczynienia z niej instrumentu administracyjnoprawnego. Mimo pewnego rodzaju odmienności nieustannie stanowi ona jeden z trybów zawarcia umowy cywilnoprawnej, jest czynnością zmierzającą do zawarcia umowy $\mathrm{w}$ trybie ofertowym ${ }^{20}$. W dążeniu do poszerzenia charakterystyki omawianej oferty warto odwołać się do zawartości art. 12 ust. 1 i 2 u.p.w.i.s.p. Na jego podstawie można twierdzić, że tworzące ofertę warunki ponownego wykorzystywania ISP, jak też opłaty z tym związane mogą mieć zastosowanie wobec wszystkich gwarantowanych przez u.p.w.i.s.p. form udostępnienia i przekazania ISP. To implikuje słuszność stanowiska, w którego świetle oferta może być (jest) skierowana do nieograniczonego kręgu adresatów, a jej postanowienia powinny być generalne i łatwe $\mathrm{w}$ swej realizacji, aby korzystanie z propozycji umowy było wykonalne bez każdorazowego jej uzgadniania w trybie wnioskowym ${ }^{21}$.

16 Zob. Zarys prawa cywilnego, red. E. Gniewek, P. Machnikowski, Warszawa 2014, s. 156, 157; oraz Z. Radwański, A. Olejniczak, Prawo cywilne - część ogólna, Warszawa 2016, s. 307.

17 Zob. Zarys prawa cywilnego..., s. 157.

18 Ibidem, s. 156-157.

19 B. Fisher et al., op. cit.

20 Ibidem.

${ }^{21}$ Ibidem. 
Uregulowania u.p.w.i.s.p. dopuszczają dwa sposoby przyjęcia propozycji zawarcia umowy, w zależności od przyjętego trybu udostępniania:

1. wyraźny, w drodze zawiadomienia przez zainteresowanego o przyjęciu oferty. Wnioskodawca, który otrzymał ofertę, może w terminie 14 dni od dnia otrzymania oferty złożyć sprzeciw z powodu naruszenia przepisów ustawy, bądź też zawiadomić podmiot zobowiązany o jej przyjęciu. Brak zawiadomienia o przyjęciu oferty jest równoznaczny $z$ wycofaniem wniosku przez zainteresowanego informacyjnie $-z$ nieprzyjęciem oferty (art. 23 ust. 2 u.p.w.i.s.p.). Tryb wyraźnego przyjęcia oferty dotyczy również procedury udostępniania ISP zainicjowanej w oparciu o wniosek dotyczący umożliwienia zainteresowanemu korzystania przez okres nie dłuższy niż 12 miesięcy w sposób stały, w czasie rzeczywistym $\mathrm{z}$ danych gromadzonych i przechowywanych $\mathrm{w}$ systemie teleinformatycznym. W tym wypadku ustawodawca w sposób wyraźny determinuje czas związania ofertą, albowiem oblat ma 14 dni na przyjęcie oferty i czyni to w drodze zawiadomienia;

2. milczący, przez przystąpienie do korzystania z informacji udostępnionych bezwnioskowo. Czynny akt w postaci ponownego wykorzystania ISP (korzystania) przez użytkownika $z$ upublicznionych danych w systemie teleinformatycznym, a w szczególności na stronie BIP lub w CR, uważa się za przyjęcie oferty (art. 12 ust. 3 u.p.wi.s.p.).

Wskutek wymienionych oświadczeń (propozycji i jej przyjęcia) dochodzi do zawarcia umowy, której treścią jest korzystanie z ISP na warunkach określonych w kontrakcie lub konieczność poniesienia opłaty związanej z kosztami jej przygotowania lub też przekazania. To prowadzi do konstatacji, że w chwili składania oferty powinna ona mieć już taką treść, która jest wymagana do zawarcia ostatecznej umowy o ponowne wykorzystywanie ISP ${ }^{22}$. Ustawodawca w treści u.p.w.i.s.p. uwidacznia występowanie również innego rodzaju kontraktu. Co istotne, to właśnie w jego zakresie w sposób wyraźny posługuje się pojęciem umowy, kreując $\mathrm{z}$ niej prawnie gwarantowane odstępstwo od przestrzegania określonej w art. 9 zasady wyłączności. Jeżeli bowiem prawidłowe wykonywanie zadań publicznych wymaga ograniczenia korzystania z ISP przez innych użytkowników, podmiot zobowiązany może zawrzeć umowę o udzielenie wyłącznego prawa do korzystania $\mathrm{z}$ tej informacji. Tego rodzaju umowa podlega corocznej ocenie, co do istnienia powodów jej zawarcia. W razie stwierdzenia ustania powodów jej obowiązywania wypowiedzenie umowy następuje w trybie natychmiastowym.

Występująca w obrębie przedmiotowej procedury instytucja umowy stanowi zbiór oświadczeń woli strony zainteresowanej i zobowiązanej informacyjnie. Jako tego rodzaju forma nie występuje po to, aby zastąpić akty administracyjne, czy też czynności materialnotechniczne. W swej istocie jest przykładem formy działania

22 Ł. Nosarzewski, Rozpatrzenie wniosku o ponowne wykorzystywanie informacji sektora publicznego, „Informacja w administracji publicznej” 2020, nr 1, Legalis (dostęp: 3.03.2021). 
właściwej prawu prywatnemu. Niemniej jednak, w związku ze specyfiką postępowania, w obrębie którego ona występuje, pociąga za sobą pytania o to, jakiego rodzaju cechy faktycznie przejawia przy uwzględnieniu wyróżnianego w doktrynie prawa administracyjnego podziału na umowy publicznoprawne, prywatnoprawne, mieszane i związaną z tym podziałem ogólną ich charakterystykę. A. Piskorz-Ryń wskazuje, że instytucja ponownego wykorzystywania ISP stanowi przedmiot regulacji administracyjnej, co wynika z normy kompetencyjnej określonej w treści art. 3 u.p.w.i.s.p., ale zakres uprawnień i obowiązków podmiotów uprawnionych informacyjnie i zobowiązanych jest zdeterminowany również regulacjami prawa cywilnego ${ }^{23}$. Uwidacznia się $\mathrm{w}$ to $\mathrm{w}$ szczególności w kontekście umów związanych z ponownym wykorzystywaniem ISP. Umowa jest wyróżniona w u.p.w.i.s.p., choć błędem byłoby stwierdzenie, że jest uregulowana tymi przepisami. Regulacje u.p.w.i.s.p. w tym przedmiocie są fragmentaryczne i w zdecydowanej większości odnoszą się do instytucji właściwej prawu cywilnemu - oferty. W piśmiennictwie można odnaleźć liczne stanowiska potwierdzające, że oferta określająca warunki ponownego wykorzystywania ISP czy też wskazująca na wysokość opłaty koniecznej do poniesienia, prowadzi lub może prowadzić wskutek jej przyjęcia do zawarcia umowy cywilnoprawnej ${ }^{24}$. Nie jest tajemnicą, że ma ona szczególny charakter - jest hybrydą, albowiem będąc umową cywilnoprawną, merytorycznie dotyka sfery właściwej prawu administracyjnemu, bo ponownego wykorzystywania ISP. Jej treść odnosi się do korzystania z wiedzy, która w zdecydowanej większości przypadków jest wiedzą publiczną, o której mowa w art. 1 ust. 1 u.d.i.p. Podmiotami niniejszej umowy z jednej strony (co do zasady) jest podmiot publiczny (art. 3 u.p.w.i.s.p.), z drugiej zaś podmiot prywatny. Ponadto w żadnym razie umowa, o której mowa, na gruncie uregulowań u.p.w.i.s.p. nie dochodzi do skutku w drodze negocjacji między podmiotem zobowiązanym a zainteresowanym informacyjnie. Niemożliwym jest również doszukanie się w jej przypadku całkowitego porzucenia władztwa podmiotu zobowiązanego informacyjnie i jednostronności jego działania na rzecz dwustronności. Proponowane warunki, „na mocy których” możliwym może stać się korzystanie z ISP, są w znacznej mierze uregulowane treścią u.p.w.i.s.p., co do zasady wychodzą od podmiotu zobowiązanego i mogą być przyjęte lub też nie przez drugą ze stron. Nie podlegają typowym dla umów cywilnoprawnych uzgodnieniom, choć zainteresowany może ubiegać się o wykorzystywanie ISP na innych warunkach lub też o całkowite uwolnienie od nich (art. 21 ust. 1 pkt. 3 u.p.w.i.s.p.) ${ }^{25}$. W obliczu stwierdzenia naruszenia przepisów

23 A. Piskorz-Ryń, Ponowne wykorzystywanie informacji sektora publicznego. Zagadnienia administracyjnoprawne, LEX (dostęp: 5.03.2021).

24 Zob. m.in. D. Sybilski, Nowelizacja ustawy o ponownym wykorzystywaniu informacji sektora publicznego dostosowujaca do przepisów ogólnego rozporządzenia o ochronie danych osobowych, Dodatek do „Monitora Prawniczego” 2019, nr 22, Legalis (dostęp: 5.03.2021).

${ }_{25} \mathrm{~W}$ myśl art. 21 ust. 1 pkt 3 u.p.w.i.s.p. ustawodawca dopuszcza bowiem również wnioskowanie, którego przedmiotem jest określenie innych warunków niż wyznaczone lub zezwolenie na ponowne 
prawa podmiot zainteresowany ma prawo do wniesienia sprzeciwu w myśl art. 23 ust. 2 u.p.w.i.s.p. To z kolei $\mathrm{w}$ jeszcze większym stopniu uwypukla właściwości nietypowe dla kategorii umów (jako form działania) i naruszeń związanych z procedurą ich zawierania, albowiem prowadzi do arbitralnego rozstrzygnięcia o warunkach lub opłatach w drodze decyzji administracyjneje ${ }^{26}$. Przy uwzględnieniu przedstawionych wcześniej właściwości można by pokusić się o twierdzenie, że omawiane umowy mają cechy właściwe kontraktom o charakterze mieszanym. W rzeczywistości bowiem uwidacznia się przewaga ich publiczno-administracyjnych cech nad cechami prywatno-cywilistycznymi. W ich ramach to stosunek zobowiązaniowy zawiera elementy publicznoprawne, a podmiot publiczny (w tym wypadku zobowiązany informacyjnie) dysponuje kompetencjami władczymi, zakładającymi jednostronne działanie wobec kontrahenta umowy (w zakresie wyznaczenia warunków ponownego wykorzystywania lub wysokości opłaty z nim związanej ${ }^{27}$. W przypadku jednak naruszenia warunków umowy zastosowanie mają ogólne zasady odpowiedzialności cywilnej z tytułu niewykonania lub też nienależytego wykonania umowy.

Tego rodzaju umowa nie dotyczy wspólnego wykonywania zadań publicznych, powierzenia bądź przekazywania realizacji zadań przez podmiot publiczny. Nie dotyka takich sytuacji, w których obrębie w odmiennym przypadku musiałby być wydany akt administracyjny, co jest charakterystyczne dla umów o typowym publicznoprawnym charakterze. Całokształt przedstawionych właściwości potwierdza zasadność twierdzeń pierwszego nurtu poglądów prawa administracyjnego na umowy w administracji. Zwolennicy tego nurtu podnoszą, że umowy w administracji są narzędziami prawa cywilnego, w ramach których jedna ze stron jest podmiotem publicznym ${ }^{28}$. Stosunki zobowiązaniowe mają charakter prywatnoprawny, a kształtowanie swoistego - administracyjnoprawnego prawa zobowiązań nie powinno mieć miejsca, gdy tego rodzaju umowy nie rządzą się własnymi prawami, ale wykazują nieco zmodyfikowany charakter standardowych umów cywilnoprawnych ${ }^{29}$. Tym samym przedmiotowa umowa stanowi cywilistyczny instrument wykonania czynności administracyjnej podmiotu publicznego w zakresie wyznaczenia warunków ponownego wykorzystywania ISP lub w zakresie określenia wysokości opłat będących następstwem realizowanej czynności.

wykorzystywanie ISP bez określenia jakichkolwiek warunków; zob. D. Sybilski, Warunki ponownego wykorzystywania informacji sektora publicznego, „Informacja w administracji publicznej” 2017, nr 4, Legalis (dostęp: 6.03.2021).

26 Zob. w przedmiocie ogólnych cech umów: Prawo administracyjne..., s. 351-354; J. Zimmermann, op. cit., s. 331-340; oraz E. Ochendowski, Prawo administracyjne, Toruń 2006, s. 210-211.

${ }^{27}$ L. Staniszewska, Zagadnienia konstrukcyjne umów publicznoprawnych, „Studia Prawa Publicznego" 2019, nr 3, s.150.

28 Ibidem, s. 141-142.

29 W.J. Jaworski, Nauka prawa administracyjnego. Zagadnienia ogólne, Warszawa 1924, s. 174; oraz M. Zimmermann, Nauka administracji i prawo administracyjne, Poznań 1949, s. 70, za: L. Staniszewska, op. cit., s. 142. 


\section{ADMINISTRACYJNOPRAWNE FORMY DZIAŁANIA}

Z występującą na gruncie u.p.w.i.s.p. zasadą kontroli instancyjnej wiąże się wykorzystywanie formy typowej w działalności organów administracji publicznej — aktów administracyjnych. W myśl art. 25 ust. 1 u.p.w.i.s.p. w zakresie nieuregulowanym ustawą (u.p.w.i.s.p.) do decyzji o odmowie wyrażenia zgody na ponowne wykorzystywanie informacji sektora publicznego oraz do decyzji o warunkach ponownego wykorzystywania lub o wysokości opłat za ponowne wykorzystywanie stosuje się przepisy ustawy z dnia 14 czerwca 1960 roku — Kodeks postępowania administracyjnego. Chodzi w tym wypadku o dopuszczalność zaskarżania $\mathrm{w}$ administracyjnym toku instancji decyzji administracyjnych wydawanych w obrębie postępowania o ponowne wykorzystywanie ISP. Jak wynika z zawartości art. $104 \S 1$ i 2 k.p.a., organ administracji załatwia sprawę przez wydanie decyzji, chyba że przepisy kodeksu stanowią inaczej. Decyzja administracyjna rozstrzyga sprawę co do istoty (w całości lub w części) albo w inny sposób kończy postępowanie w danej sprawie. Tego rodzaju definiowanie, w szczególności zaś pierwsza jego część, odzwierciedla istotę decyzji występujących na gruncie u.p.w.i.s.p. Ustawodawca, posługując się kategorią indywidualnego, konkretnego i zewnętrznego aktu stosowania prawa, przewiduje możliwość odmowy wyrażenia zgody na ponowne wykorzystywanie ISP, jak również dopuszczalność rozstrzygnięcia o warunkach ponownego wykorzystania ISP oraz o wysokości opłaty za ponowne wykorzystywanie. Potwierdza to tym samym stanowisko wyrażone $\mathrm{w}$ jednym $\mathrm{z}$ wyroków NSA, stosownie do którego działanie organów w formie decyzji ma wynikać z przepisu w sposób niepozbawiający wątpliwości, że rozstrzygnięcie ma charakter decyzji ${ }^{30}$. W obrębie procederu związanego z przekazywaniem udostępnieniem) ISP $\mathrm{w}$ celu ponownego jej wykorzystywania, można wyodrębnić dwa rodzaje decyzji:

1. związaną z zasadą limitowania dostępu do ISP $\mathrm{w}$ granicach określonych przez prawo, to jest ze względu na art. 6 u.p.w.i.s.p. i wyodrębnione tam wartości wymagające ochrony oraz inne ustawowe ograniczenia (decyzja przymusowa) ${ }^{31}$. Ponadto podmiot zobowiązany informacyjnie może odmówić wyrażenia zgody na ponowne wykorzystywanie ISP, wówczas gdy utworzenie lub przetworzenie informacji w sposób lub też w formie określonej przez zainteresowanego, jak również gdy sporządzenie z niej wyciągów pociąga za sobą konieczność podejmo-

30 Zob. wyrok NSA z dnia 16 lipca 1982 r., SA/Wr 220/82, https://sip.lex.pl/orzeczenia-i-pisma-urzedowe/orzeczenia-sadow/sa-wr-220-82-wyrok-naczelnego-sadu-administracyjnego-do-520103389 (dostęp: 10.07.2020).

31 Zob. wyrok WSA w Warszawie z dnia 5 czerwca 2019 r., II SA/Wa 95/19, CBOSA, http://orze czenia.nsa.gov.pl/doc/12FFC1BE2A (dostęp: 8.03.2021); wyrok WSA w Warszawie z dnia 4 października 2019 r., II SAB/Wa 379/19, CBOSA, http:/orzeczenia.nsa.gov.pl/doc/FE12C8CE5B (dostęp: 8.03.2021); wyrok WSA w Lublinie z dnia 3 marca 2020 r., II SAB/ Lu 101/19, CBOSA, http://orzeczenia.nsa.gov.pl/doc/DD27ED1A93 (dostęp: 3.03.2021); wyrok NSA z dnia 11 czerwca 2019 r., I OSK 1921/17, CBOSA, http://orzeczenia.nsa.gov.pl/doc/DD27ED1A93 (dostęp: 8.03.2021). 
wania nieproporcjonalnych działań, takich które wykraczają poza ramy realizacji prostych czynności (decyzja dobrowolna - art. 10 ust. 2 u.p.w.i.s.p.). Ukształtowana w tym wypadku możność postępowania (bo podmiot może) opiera się na prawie wyboru zobowiązanego do zadecydowania o przekazaniu ISP (mimo konieczności podejmowania ponadprzeciętnych czynności) bądź też na powstrzymaniu się od przekazania danych i wydaniu decyzji administracyjnej o odmowie. $\mathrm{W}$ żadnym jednak razie owej dobrowolności nie należy utożsamiać $\mathrm{z}$ legitymacją do przesądzania o sposobie dokonania rozstrzygnięcia w tym przedmiocie ${ }^{32}$. Rezygnacja $\mathrm{z}$ decyzji administracyjnej jako formy rozstrzygnięcia $\mathrm{w}$ omawianym zakresie jest niedopuszczalna. Ustawodawca przewiduje wyłącznie dwie postacie postępowania zobowiązanego: aktywne działanie zgodne z intencją zainteresowanego lub wręcz przeciwnie - bierność odnajdującą swoje umocowanie w treści u.p.w.i.s.p., potwierdzoną zawartością aktu administracyjnego;

2. związaną z odejściem od zasady bezwarunkowego udostępniania ISP, określającą warunki ponownego wykorzystywania ISP (decyzja warunkująca), wówczas gdy podmiot zainteresowany zgłosi sprzeciw wobec oferty przedstawiającej te warunki lub wobec określonej wysokości opłaty tytułem ponownego wykorzystywania ISP.

Ustawodawca, odmiennie do uregulowań u.d.i.p., nie przewiduje występowania decyzji umarzających. W obrębie uregulowań dostępowych (u.d.i.p.) niemożność udostępnienia informacji publicznej adekwatnie do wniosku zainteresowanego, po uprzednim zawiadomieniu drugiej strony, określeniu możliwej do wykorzystania formy i sposobu oraz jednoczesnej bierności ze strony zainteresowanego, informacyjnie skutkuje wydaniem decyzji umarzającej postępowanie (art. 14 u.d.i.p.). Identycznego rozwiązania nie sposób odnaleźć w świetle uregulowań u.p.w.i.s.p., choć odwołanie się do zasady proporcjonalności określonej $\mathrm{w}$ art. 10 ust. 2 uwidacznia pewnego rodzaju podobieństwo w postaci niemożności działania podmiotu zobowiązanego informacyjnie i jedocześnie odmiennego do uregulowań u.d.i.p. sposobu rozstrzygnięcia sprawy. Prawnie sankcjonowana niemożność przygotowania czy też przetworzenia ISP, jak również sporządzenia $\mathrm{z}$ niej wyciągu z racji nieproporcjonalności działań podmiotu zobowiązanego informacyjnie, może pociągać za sobą decyzję odmowną, a nie umarzającą postępowanie w danej sprawie. Ustawodawca na gruncie uregulowań u.p.w.i.s.p. nie reguluje sytuacji związanych z decyzjami, które w inny sposób kończą postępowanie w danej sprawie. Wydaje się to tym bardziej zaskakujące, jeśli weźmiemy pod uwagę zawartość art. 23 ust. 2 u.p.w.i.s.p. W jego ramach dochodzi do (milczącego, ale jednak) wycofania wniosku przez zainteresowanego, co powinno pociągać za sobą (podobnie jak na gruncie u.d.i.p.) umorzenie postępowania w danej sprawie. Ustawodawca ponadto nie determinuje procedury umorzenia, wówczas gdy zainteresowany jeszcze przed podjęciem aktywności przez drugą stronę zmienia

32 B. Fisher et al., op. cit. 
zdanie względem dochodzenia swoich uprawnień konstytucyjnych i decyduje się na wycofanie wniosku o przekazanie (udostępnienie) ISP.

Analiza uregulowań u.p.w.i.s.p. odwołuje się do decyzji administracyjnej kwalifikowanej jako stanowczy, podjęty w procedurze przejaw zachowania podmiotu zobowiązanego informacyjnie, działającego na podstawie przepisów prawa i w ramach prawnie przyznanych mu kompetencji, zmierzający do wywołania skutków prawnych w postaci uniemożliwienia korzystania z ISP wbrew uprawnieniu konstytucyjnemu lub też odwołujący się do określonych warunków ponownego wykorzystywania ${ }^{33}$. Doktrynalnie decyzje administracyjne są przejawem:

- jednostronnego, zewnętrznego oraz konkretnego rozstrzygnięcia strony zobowiązanej;

— podejmowanego za zgodą drugiej strony (bo wyłącznie na podstawie uprzednio przedłożonego wniosku), mimo iż zgoda dotyczy tu kwestii podjęcia rozstrzygnięcia, a nie samej treści; intencją zainteresowanego nigdy nie będzie otrzymanie decyzji negatywnej. Podobnym twierdzeniem można by się posłużyć wobec decyzji rozstrzygającej o warunkach. Najoptymalniejszym bowiem rozwiązaniem dla zainteresowanego jest korzystanie z ISP bezwarunkowo, tym bardziej jeśli na ukształtowanie przesłanek warunkujących nie ma on żadnego wpływu. Trudne zatem jest doszukiwanie się w tym wypadku zdecydowanej akceptacji ze strony zainteresowanego informacyjnie;

- o negatywnym (w zakresie decyzji odmawiających) i pozytywno-negatywnym charakterze (w zakresie decyzji rozstrzygających o warunkach, albowiem zobowiązany, uznając sprzeciw za bezzasadny, może podtrzymać warunki lub opłaty określone w ofercie lub też, uznając zasadność zgłoszonego sprzeciwu, może zadecydować o przekazaniu informacji bezwarunkowo) ${ }^{34}$.

Opowiedzenie się za konstytutywnym czy też za kształtującym charakterem decyzji w obrębie postępowań o ponowne wykorzystywanie ISP nie jest takie proste i jednoznaczne. Przedstawiciele doktryny doszukują się oparcia problematyki ponownego wykorzystywania na zawartości art. 54 oraz częściowo na art. 61 ust. 1 Konstytucji $\mathrm{RP}^{35}$. A zatem powszechnie przysługujące prawo do uzyskania informacji w celu ponownego wykorzystywania w konkretnej sytuacji (ściśle określona ISP objęta oczekiwaniem zainteresowanego oraz konkretny adresat) może prowadzić do zaspokojenia informacyjnego lub też nie, w związku z zaistnieniem przesłanek ustawowo określonych. Nie można zatem uznać, że wykorzystywana w procedurze decyzja kreuje po stronie adresata prawo lub obowiązek. Niemniej

33 Definicja oparta na stanowisku w Prawo administracyjne..., s. 321.

34 Zob. w przedmiocie ogólnych cech aktu administracyjnego: ibidem, s. 321-328; J. Zimmermann, Prawo administracyjne..., s. 283-294; oraz E. Ochendowski, op. cit., s. 185-192; zob. B. Pietrzak, Sprzeciw od oferty zawierajacej warunki ponownego wykorzystywania informacji sektora publicznego, „Informacja w administracji publicznej” 2017, nr 4, Legalis (dostęp: 6.03.2021).

35 Zob. m.in. K. Chałubińska, op. cit., s. 95; P. Sitniewski, Ustawa o ponownym wykorzystywaniu informacji sektora publicznego. Komentarz, Warszawa 2017, s. 5 n. 
jednak, wobec generalnego, konstytucyjnego uprawnienia, dookreślonego ustawą, można stwierdzić, że decyzja odmawiająca lub też warunkująca modyfikuje sytuację zainteresowanego w ten sposób, że nie uzyskuje on informacji, zgodnie ze swoimi aspiracjami, i nie może z niej korzystać bądź też może ją ponownie wykorzystywać wedle zasad (warunków) uprzednio ustalonych (aprobowanych lub też nie). W tym miejscu uwidacznia się nietypowy, choć twórczy charakter rozstrzygnięcia pochodzącego od podmiotu zobowiązanego informacyjnie.

\section{ZAKOŃCZENIE}

Reasumując rozważania, należy wskazać, że w obrębie procedury związanej z ponownym wykorzystywaniem ISP występują niemal wszystkie kategorie działań kwalifikowane przez doktrynę jako prawne formy postępowania organów administracji publicznej. Z punktu widzenia posiadanych właściwości zasadniczo (poza umową) nie odbiegają one od teoretycznych założeń, które są kreowane przez piśmiennictwo wobec poszczególnych typów działań podmiotów administracji. Ich łączne rozpatrywanie prowadzi do konstatacji o połączeniu w obrębie jednej procedury elementów cywilnoprawnych i administracyjnoprawnych oraz dostrzeżenie częściowego odchodzenia od przymusu administracyjnego w ramach postępowania o przekazanie (udostępnienie) ISP. Posłużenie się w tym wypadku określeniem wskazującym na jedynie częściową rezygnację z władczości i oficjalności nie ma charakteru przypadkowego. Mimo bowiem wyraźnego oddziaływania prawa cywilnego na instytucję ponownego wykorzystywania ISP nie można opowiedzieć się za wykorzystywaniem w jej ramach rozwiązań typowo koncyliacyjnych czy konsensualnych ${ }^{36}$.

Zawartość uregulowań u.p.w.i.s.p. pozwala stwierdzić, że odwrócony został schemat odwołujący się do stopniowania ważności poszczególnych form działania przez wzajemne „przesunięcie” aktów administracyjnych i działań faktycznych. To tym drugim $\mathrm{z}$ wymienionych należy przypisać podstawowe znaczenie $\mathrm{w}$ procesie związanym z udostępnieniem ISP, jeśli za pewnego rodzaju wyznacznik $\mathrm{w}$ tym przedmiocie weźmiemy oczekiwania podmiotów zainteresowanych informacyjnie. To jednak nie zmienia faktu, że każdy z omówionych typów działań jest zastrzeżony dla odrębnej kategorii zachowań, zgodnych z wymaganiami zainteresowanego lub też nie, każdy z nich ma swoją ustawowo przypisaną rolę i istotność w procedurze, choć inna jest treść ich realizacji.

${ }^{36}$ Zob. stanowisko J. Zimmermanna, Jedność prawa administracyjnego, [w:] Między tradycja a przyszłościa w nauce prawa administracyjnego. Księga jubileuszowa dedykowana Profesorowi Janowi Bociowi, red. J. Supernat, Wrocław 2009, s. 814. 


\title{
ADMINISTRATIVE LAW, CIVIL LAW, AND OTHER FORMS OF ACTION IN PROCEEDINGS FOR DISCLOSURE OF INFORMATION FOR RE-USE
}

\author{
Summary
}

The provision of information, refusal to provide access, determination of conditions as to the behaviour occurring within the framework of proceedings regulated by the Act of 25 February 2016 on the re-use of public sector information shall take the forms which are commonly used within the framework of public administration activities. In this case, these are factual actions, contracts, and administrative decisions doctrinally defined as legal forms of action and used by entities obliged to provide information when the entity executes its interest in providing information by way of an application, as well as regardless of the behaviour of the entitled party ex officio (without an application). The present study is devoted to the discussion of these categories of activity, recalling their properties and importance in the process of making information available for re-use.

Keywords: re-use, form of action, public sector information, decision, act

\section{BIBLIOGRAFIA}

Chałubińska-Jentkiewicz K., Ponowne wykorzystanie informacji sektora publicznego (re-use). Komentarz do ustawy, Warszawa 2018.

Fisher B., Piskorz-Ryń A., Sakowska-Baryła M., Wyporska-Frankiewicz J., Ustawa o ponownym wykorzystywaniu informacji sektora publicznego. Komentarz, LEX, https://sip.lex.pl/\#/com mentary/587807375/604815/fischer-bogdan-i-in-ustawa-o-ponownym-wykorzystywaniu-in formacji-sektora-publicznego-komentarz?cm=RELATIONS.

Gos A., Unowocześnienie dostępu do danych publicznych za pomoca interfejsu programistycznego aplikacji (API), „Informacja w administracji publicznej” 2018, $\mathrm{nr}$ 2, Legalis, https://sip.legalis. $\mathrm{pl} /$ document-full.seam?documentId=mjxw62zogi3damrqgq2tmni.

Jawność i jej ograniczenia, t. 5. Dostęp i wykorzystywanie, red. A. Piskorz-Ryń, Warszawa 2015.

Jaworski W.J., Nauka prawa administracyjnego. Zagadnienia ogólne, Warszawa 1924.

Liżewski S., Przekazywanie informacji publicznej do centralnego repozytorium informacji publicznej - zmiany wprowadzone tarcza antykryzysowa 2.0, „Informacja w administracji publicznej" 2020, nr 2, Legalis, https://sip.legalis.pl/document-full.seam?documentId=mjxw62zogi3damrwgq2temq.

Między tradycją a przyszłościa w nauce prawa administracyjnego. Księga jubileuszowa dedykowana Profesorowi Janowi Bociowi, red. J. Supernat, Wrocław 2009.

Nosarzewski Ł., Informacja publiczna jako przedmiot ponownego wykorzystywania, „Informacja w administracji publicznej” 2020, $\mathrm{nr}$ 4, Legalis, https://sip.legalis.pl/document-full.seam?documentId=mjxw62zogi3damrxheztmoa.

Nosarzewski Ł., Rozpatrzenie wniosku o ponowne wykorzystywanie informacji sektora publicznego, „Informacja w administracji publicznej” 2020, nr 1, Legalis, https://sip.legalis.pl/document-full.seam?documentId=mjxw62zogi3damrvga4dsmi.

Ochendowski E., Prawo administracyjne, Torun 2006.

Ostrowska A., Koncepcja umowy administracyjnej na przykładzie umowy o dotację $w$ świetle polskich i zagranicznych regulacji, „Prawo Budżetowe Państwa i Samorządu” 2018, nr 3.

Pietrzak B., Decyzja o odmowie wyrażenia zgody na ponowne wykorzystywanie informacji sektora publicznego ze względu na ochronę praw autorskich, ,Informacja w administracji publicznej” 
2016, nr 3, Legalis, https://sip.legalis.pl/document-full.seam?documentId=mjxw62zogi2dkm jugq3dcmq.

Pietrzak B., Sprzeciw od oferty zawierajacej warunki ponownego wykorzystywania informacji sektora publicznego, „Informacja w administracji publicznej” 2017, nr 4, Legalis, https://sip.lega lis.pl/document-full.seam?documentId=mjxw62zogi3damjxheydqmi.

Pietrzak-Kudelska B., Odwołanie od decyzji o odmowie wyrażenia zgody na ponowne wykorzystywanie informacji sektora publicznego ze względu na ochronę praw autorskich, „Informacja w administracji publicznej" 2018, nr 1, Legalis, https://sip.legalis.pl/document-full.seam?do cumentId=mjxw62zogi3damjzga3dknq.

Piskorz-Ryń A., Ustawa o ponownym wykorzystaniu informacji sektora publicznego. Komentarz, Wrocław 2017.

Prawo administracyjne, red. J. Boć, Wrocław 2010.

Radwański Z., Olejniczak A., Prawo cywilne - czesść ogólna, Warszawa 2016.

Sibiga G., Ponowne wykorzystywanie informacji sektora publicznego 2017. Akty prawne i ich omówienie, Wrocław 2017.

Sitniewski P., Ustawa o ponownym wykorzystywaniu informacji sektora publicznego. Komentarz, Warszawa 2017.

Staniszewska L., Zagadnienia konstrukcyjne umów publicznoprawnych, „Studia Prawa Publicznego" 2019, nr 3.

Sybilski D., Nowelizacja ustawy o ponownym wykorzystywaniu informacji sektora publicznego dostosowująca do przepisów ogólnego rozporzadzenia o ochronie danych osobowych, ,Monitor Prawniczy. Dodatek” 2019, nr 22, Legalis, https://sip.legalis.pl/document-full.seam?docu mentId=mjxw62zogi3damrugiytsnq.

Sybilski D., Warunki ponownego wykorzystywania informacji sektora publicznego, „Informacja w administracji publicznej" 2017, nr 4, Legalis, https://sip.legalis.pl/document-full.seam?do cumentId=mjxw62zogi3damjxheydooa.

Syryt A., Konstytucyjne uwarunkowania ponownego wykorzystywania informacji sektora publicznego, [w:] Jawność i jej ograniczenia, t. 5. Dostęp i wykorzystywanie, red. A. Piskorz-Ryń, Warszawa 2015.

Szustakiewicz P., Wzajemny stosunek do dwóch ustaw tworzacych polski system dostępu do informacji publicznej, „Informacja w administracji publicznej” 2017, $\mathrm{nr} 3$, Legalis, https://sip. legalis.pl/document-full.seam?documentId=mjxw62zogi3damjxgi3dmna.

Wiktorowska A., Kierunki zmian $w$ teorii prawnych form dziatania administracji, [w:] Koncepcja systemu prawa administracyjnego, red. J. Zimmermann, Warszawa 2007.

Zarys prawa cywilnego, red. E. Gniewek, P. Machnikowski, Warszawa 2014.

Ziemski K.M., Indywidualny akt administracyjny jako forma prawna działania administracji, Poznań 2005.

Zimmermann J., Prawo administracyjne, Warszawa 2008.

Zimmermann M., Nauka administracji i prawo administracyjne, Poznań 1949.

\section{WYKAZ AKTÓW PRAWNYCH}

Dyrektywa 2003/98/WE Parlamentu Europejskiego i Rady z dnia 17 listopada 2003 roku w sprawie ponownego wykorzystywania informacji sektora publicznego, Dz.Urz. UE L 345 z dnia 31.12.2003 r., s. 701-707.

Ustawa z dnia 23 kwietnia 1964 roku — Kodeks cywilny Dz.U. z 2020 r. poz. 1740 ze zm.

Ustawa z dnia 6 września 2001 roku o dostępie do informacji publicznej, Dz.U. z 2020 r. poz. 2176. 
Ustawa z dnia 16 września 2011 roku o zmianie ustawy o dostępie do informacji publicznej oraz niektórych innych ustaw, Dz.U. z 2011 r. Nr 204, poz. 1195.

Ustawa z dnia 25 lutego 2016 roku o ponownym wykorzystywaniu informacji sektora publicznego, Dz.U. z 2019 r. poz. 1446.

Ustawa z dnia 11 sierpnia 2021 roku o otwartych danych i ponownym wykorzystywaniu informacji sektora publicznego, Dz.U. z 2021 r. poz. 1641.

\section{WYKAZ ORZECZNICTWA}

Postanowienie WSA w Białymstoku z dnia 18 grudnia 2007 roku, II SA/Bk 646/07.

Wyrok NSA z dnia 16 lipca 1982 roku, SA/ Wr 220/82.

Wyrok NSA z dnia 11 czerwca 2019 roku, I OSK 1921/17.

Wyrok WSA w Lublinie z dnia 3 marca 2020 roku, II SAB/ Lu 101/19.

Wyrok WSA w Szczecinie z dnia 10 stycznia 2013 roku, II SAB/Sz 51/12.

Wyrok WSA w Warszawie z dnia 5 czerwca 2019 roku, II SA/Wa 95/19.

Wyrok WSA w Warszawie z dnia 4 października 2019 roku, II SAB/Wa 379/19. 